\title{
PEMBENTUKAN KARAKTER ANAK USIA DINI \\ MELALUI PEMBIASAAN
}

\author{
Amilda \\ Program Studi Pendidikan Islam Anak Usia Dini - Fakultas Ilmu Tarbiyah dan Keguruan \\ Universitas Islam Negeri Raden Fatah \\ amildagandi@yahoo.co.id
}

\begin{abstract}
Abstrak: Anak memiliki karakteristik dan merupakan individu unik, yang mempunyai pengalaman dan pengetahuan yang berbeda, maka perlu dilakukan usaha yaitu dengan memberikan rangsangan-rangsangan, dorongan-dorongan, dan dukungan kepada anak. Agar para pendidik dapat melakukan dengan optimal maka perlu dikenalkan pada kebiasaan-kebiasaan baik. Selanjutnya, untuk merealisasikan hal itu perlu kiranya pelaksanaan kegiatan pendidikan pada anak usia dini serta peran serta para pendidik untuk senantiasa mencari berbagai metode yang efektif, serta mencari kaidah-kaidah pendidikan yang berpengaruh dalam mempersiapkan dan membantu pertumbuhan anak usia dini, baik secara mental dan moral, spiritual dan etos sosial, sehingga anak dapat mencapai kematangan yang sempurna guna menghadapi kehidupan dan pertumbuhan selanjutnya. Berkaitan dengan hal itu, pembiasaan merupakan bagian dari metode mendidik anak yang tujuannya adalah untuk membentuk tingkah laku anak dan mengurangi perilaku yang buruk, dengan demikian maka akan muncul pola perilaku baru yang relative menetap dan otomatis, inilah yang dinamakan karakter. Dalam perspektif Islam karakter berarti akhlak, Jadi, proses pembentukan karakter itu menunjukkan keterkaitan yang erat antara fikiran, perasaan dan tindakan. Dari wilayah akal terbentuk cara berfikir dan dari wilayah fisik terbentuk cara berperilaku. Cara berfikir menjadi visi, cara merasa menjadi mental dan cara berperilaku menjadi karakter. secara sederhana ada beberapa hal yang dapat dianggap positif untuk dibiasakan terhadap anak usia dini, di antaranya adalah Anak harus dibiasakan menjaga kebersihan, sebab Islam sangat mementingkan kebersihan. Anak dilatih dan dibiasakan hidup teratur, misalnya dengan membiasakan anak makan secara teratur dan tidak berlebihan. Anak sejak dini hendaknya dibiasakan hidup sederhana dan hemat.
\end{abstract}

Kata kunci: karakter, pembiasaan

\section{Pendahuluan}

Dalam pandangan Islam anak merupakan amanah di tangan kedua orang tuanya. Hatinya yang bersih merupakan permata yang berharga, lugu dan bebas dari segala macam ukiran dan gambaran. Ukiran berupa didikan yang baik akan tumbuh subur pada diri anak, sehingga ia akan berkembang dengan baik dan sesuai 
ajaran Islam, dan pada akhirnya akan meraih kebahagiaan di dunia dan di akhirat. Jika anak sejak dini dibisakan dan dididik dengan hal-hal yang baik dan diajarkan kebaikan kepadanya, ia akan tumbuh dan berkembang dengan baik dan akan memperoleh kebahagiaan serta terhindar dari kesengaraan/siksa baik dalam hidupnya di dunia maupun di akhirat kelak. Hal ini senada dengan firman Allah:

Artinya: "Hai orang-orang
yang beriman, peliharalah
dirimu dan keluargamu dari api
neraka yang bahan bakarnya
adalah manusia dan batu;
penjaganya malaikat-malaikat
yang kasar, yang keras, yang
tidak mendurhakai Allah
terhadap apa yang
diperintahkan-Nya kepada
mereka dan selalu
mengerjakan apa yang
diperintahkan. (At Tahrim: 6)

Sehubungan dengan ayat tersebut, Ali Quthb (1988: 59) berpandangan bahwa orang tua memiliki kewajiban untuk memelihara diri dan keluarga (anakanaknya) dari siksaan api neraka. Cara yang dapat dilakukan oleh orang tua ialah mendidiknya, membimbingnya dan mengajari akhlak-akhlak yang baik. Kemudian orang tua harus menjaganya dari pergaulan yang buruk, dan jangan membiasakannya berfoya-foya, jangan pula orang tua menanamkan hidup dengan sarana-sarana kemewahan pada diri anak, sebab kelak anak akan menyia-nyiakan umurnya hanya untuk mencari kemewahan jika ia tumbuh menjadi dewasa, sehingga ia akan binasa untuk selamanya. Akan tetapi seharusnya orang tua sejak dini mulai mengawasi pertumbuhannya dengan cermat dan bijaksana sesuai dengan tuntutan pendidikan Islam. Dalam rangka mengoptimalkan perkembangan anak dan memenuhi karakteristik anak yang merupakan individu unik, yang mempunyai pengalaman dan pengetahuan yang berbeda, maka perlu dilakukan usaha yaitu dengan memberikan rangsangan-rangsangan, dorongandorongan, dan dukungan kepada anak. Agar para pendidik dapat melakukan dengan optimal maka perlu dikenalkan pada kebiasaankebiasaan baik. Selain pembentukan sikap dan perilaku yang baik, anak juga memerlukan kemampuan intelektual agar anak siap menghadapi tuntutan masa kini dan masa datang. Sehubungan dengan itu 
maka program pendidikan dapat mencapai hasil yang mencakup bidang pembentukan sikap dan pengembangan kemampuan dasar yang keseluruhannya berguna untuk mewujudkan manusia sempurna yang mampu berdiri sendiri, bertanggung jawab dan mempunyai bekal untuk memasuki pendidikan selanjutnya. Karenanya, para ahli pendidikan pun harus merumuskan sebuah kurikulum untuk anak usia dini dengan memperhatikan beberapa prinsip. Pertama, berpusat pada anak, artinya anak merupakan sasaran dalam kegiatan pembelajaran yang dilakukan oleh pendidik. Kedua, mendorong perkembangan fisik, daya pikir, daya cipta, sosial emosional, bahasa dan komunikasi sebagai dasar pembentukan pribadi manusia yangh utuh. Ketiga, memperhatikan perbedaan anak, baik perbedaan keadaan jasmani, rohani, kecerdasan dan tingkat perkembangannya. Pengembangan program harus memperhatikan kesesuaian dengan tingkat perkembangan anak (Developmentally Appropriate Program). (Halim, 2001: 25)

$$
\text { Untuk }
$$
merealisasikan

pelaksanaan kegiatan pendidikan pada anak usia dini serta guna menggembirakan, para pendidik hendaklah senantiasa mencari berbagai metode yang efektif, serta mencari kaidah-kaidah pendidikan yang berpengaruh dalam mempersiapkan dan membantu pertumbuhan anak usia dini, baik secara mental dan moral, spiritual dan etos sosial, sehingga anak dapat mencapai kematangan yang sempurna guna menghadapi kehidupan dan pertumbuhan selanjutnya. Dengan bersumberkan kepada Al Qur-an dan hadis, ada beberapa upaya yang dapat dilakukan untuk penanaman karakter melalui kegiatan pendidikan terhadap anak usia dini melalui kebiasaankebiasaan baik di lingkungan sekolah maupun di keluarga.

\section{Pembahasan}

Landasan Pendidikan Anak Usia Dini

Menurut Sujiono (2011: 8-10), penyelenggaraan PAUD/PGRA didasarkan pada beberapa landasan, yakni landasan yuridis, landasan filosofi dan religius serta landasan keilmuan secara teoritis maupun empiris.

1. Landasan Yuridis. 
Pendidikan Anak Usia Dini

merupakan bagian dari pencapaian tujuan pendidikan nasional, sebagaimana diatur dalam UndangUndang Nomor 2 Tahun 1989 tentang Sistem Pendidikan Nasional yaitu mencerdaskan kehidupan bangsa dan mengembangkan manusia Indonesia seutuhnya yaitu manusia yang beriman dan bertaqwa kepada Tuhan Yang Maha Esa dan berbudi luhur, memiliki pengetahuan dan keterampilan, kesehatan jasmani dan rohani, kepribadian yang mantap dan mandiri serta rasa tanggung jawab kemasyarakatan dan kebangsaan. Melihat fungsi dan tujuan pendidikan yang telah diteteapkan oleh pemerintah di atas, memberikan makna bahwa sehebat apapun potensi berkembang, bangsa ini tetap berkeinginan untuk melandasinya dengan pilar keimanan dan ketakwaan kepada Tuhan yang Maha Esa. Sehingga ibarat bangunan yang akan dibentuk maka fondasi yang kuat akan mampu menjamin terbentuknya sebuah bangunan fisik yang kokoh dan tidak goyah. Semua landasan yuridis ini tentu mengingatkan pada hal yang esensial dari pranata sosial kehidupan bangsa ini, yang sangat mengagungkan makna ajaran agama dalam kehidupannya.

2. Landasan Filosofi dan Religius Pendidikan dasar anak usia dini pada dasarnya berdasarkan pada nilai-nilai filosofi dan religi yang dipegang oleh lingkungan yang berada disekitar anak dan agama yang dianutnya. Dalam Islam dikatakan bahwa "seorang anak terlahir dalam keadaan firah/islam/lurus, orang tualah yang membuat anaknya menjadi yahudi, nasrani dan majusi," maka bagaimana kita bisa menjaga dan meningkatkan potensi kebaikan tersebut dan hal itu tentunya harus dimulai sejak usia dini. Ketika manusia dilahirkan ke dunia, tak satupun orang yang dilahirkan berada dalam kesempurnaan, baik dalam pandangan fisik maupun rohani. Ketidaksempurnaan manusia itu merupakan pertanda bahwa betapa manusia memerlukan bantuan orang lain, pendidikan, aturan hidup, dan kelengkapan hidup lainnya. Salah satu kelengkapan hidup yang akan mampu menghantarkan manusia dalam kehidupannya untuk mencapai martabat yang mulia adalah 
dibutuhkannya ajaran nilai-nilai keagamaan. Ajaran agama berasal dari Tuhan Yang Maha Pencipta, pemilik alam semesta, yang berhak membuat aturan hidup bagi makhluk yang diciptakannya. Ontologis, anak sebagai makhluk individu yang mempunyai aspek biologis, psikologis, sosiologis, antropologis. Secara Epistimologis, pembelajaran pada anak usia dini hendaknya menggunakan konsep belajar sambil bermain (learning by playing), belajar sambil berbuat (learning by doing), dan belajarmelalui stimulasi (learning by stimulating). Selain itu secara Aksiologis, isi kurikulum hendaknya benar dandapat dipertanggungjawabkan dalam kerangka optimalisasi seluruh potensi anak dan berhubungan dengan nilai seni, keindahan dan keselarasan yang mengarah pada kebahagiaan dalam kehidupan anak sesuai dengan akar budaya di mana mereka hidup serta nilai-nilai agama yang dianutnya.

\section{Landasan Keilmuan dan Empiris} Pendidikan anak usia dini pada dasarnya meliputi aspek keilmuan yang menunjang kehidupan anak dan terkait dengan perkembangan anak.
Konsep keilmuan PAUD/PGRA bersifat isomorfis artinya kerangka keilmuan PAUD/PGRA dinangun dari interdisplin ilmu yang merupakan gabungan dari beberapa disiplin ilmu, diantaranya; psikologi, fisiologi, sosioligi, ilmu pendidikan anak, antropologi, humaniora, kesehatan dan gizi serta neorosains. Pada saat anak dilahirkan sudah dibekali oleh Tuhan dengan struktur otak yang lengkap, namun baru mencapai kematangannya setelah pengaruh pendidikan di luar kandungan. Otak manusia terdiri dari dua belahan, kiri (left helmisphere) dan kanan (right hemisphere ) yang disambung oleh segumpal serabut yang disebut corpuss callasum. Kedua belahan otak tersebut memiliki fungsi, tugas dan respon berbeda dan harus tumbuh dalam keseimbangan. Belahan otak kiri berfungsi untuk berfikir rasional, analitis, berurutan, linier, saintifik seperti membaca, bahasa dan berhitung. Adapun belahan otak kanan berfungsi untuk mengembangkan imajinasi dan kreativitas. Bila pelaksanaan pembelajaran di PAUD/PGRA memberikan banyak pelajaran menulis, berhitung dan membaca 
seperti yang dilaksanakan dewasa ini, akan mengakibatkan fungsi imajinasi dan kreativitas pada belahan otak kanan terabaikan.

Dari segi empiris, banyak sekali penelitian yang menyimpulkan bahwa pendidikan anak usia dini sangat penting, antara lain yang menjelaskan bahwa pada waktu manusia dilahirkan, kelengkapan organisasi otak memuat 100-200 milyar sel otak yang diap dikembangkan serta diaktualisasikan mencapai tingkat perkembangan potensi tertinggi, tetapi hasil riset membuktikan bahwa hanya $5 \%$ dari potensi otak itu yang terpakai. Hal itu disebabkan kurangnya stimulasi yang mengoptimalkan fungsi otak.

\section{Pengertian Karakter}

Kata karakter (Inggris: character) secara etimologis berasal dari bahasa Yunani, yaitu charassein yang berarti "to engrave" (Ryan dan Bohlin, 1999:

5). Kata "to engrave" bisa diterjemahkan mengukir, melukis, memahatkan, atau menggoreskan (Echols dan Shadily, 2000: 214). Dalam Kamus Besar Bahasa Indonesia (KBBI) (2001: 682), kata "karakter" diartikan dengan tabiat, sifat-sifat kejiwaan, akhlak atau budi pekerti yang membedakan seseorang dengan yang lain, dan watak. Karakter juga bisa berarti huruf, angka, ruang, simbul khusus yang dapat dimunculkan pada layar dengan papan ketik. Orang berkarakter berarti orang yang berkepribadian, berperilaku, bersifat, bertabiat, atau berwatak. Dengan makna seperti itu berarti karakter identik dengan akhlak. Secara terminologis karakter adalah "A reliable inner disposition to respond to situations in a morally good way."

Selanjutnya Lickona (1991: 51)

menambahkan, "Character so conceived has three interrelated parts: moral knowing, moral feeling, and moral behavior". Menurut Lickona, karakter mulia (good character) meliputi pengetahuan tentang kebaikan (moral khowing), lalu menimbulkan komitmen (niat) terhadap kebaikan (moral feeling), dan akhirnya benar-benar melakukan kebaikan.

Dalam perspektif Islam karakter berarti akhlak, yang dalam bahasa Arab akhlaq (yang berarti tabiat, perangai, dan kebiasaan) banyak ditemukan dalam hadis Nabi 
Saw. Dalam salah satu haditsnya Rasulullah SAW. bersabda, "Sesungguhnya aku hanya diutus untuk menyempurnakan akhlak yang mulia". (HR. Ahmad). Sedangkan dalam al-Quran menurut Ainain hanya ditemukan bentuk tunggal dari akhlaq yaitu khuluq. Allah menegaskan, "Dan sesungguhnya kamu benar-benar berbudi pekerti yang agung." (QS. al-Qalam [68]: 4).

Khuluq adalah ibarat dari kelakuan manusia yang membedakan baik dan buruk, lalu disenangi dan dipilih yang baik untuk dipraktikkan dalam perbuatan, sedang yang buruk dibenci dan dihilangkan (Ainain, 1985: 186). Sementara menurut Ismail (1988: 178), kata yang setara maknanya dengan akhlak adalah moral dan etika. Kata-kata ini sering disejajarkan dengan budi pekeri, tata susila, tata krama atau sopan santun.

Teori Pembentukan Karakter Stephen Covey (2003) melalui bukunya 7 Kebiasaan Manusia Yang Sangat Efektif, menyimpulkan bahwa sebenarnya ada tiga teori utama yang mendasarinya, yaitu:

1. Determinisme Genetis, pada dasarnya mengatakan kakeknenek kitalah yang bebuat begitu kepada kita. Itulah sebabnya kita memiliki tabiat seperti ini. Kakek-nenek kita mudah marah dan itu ada pada DNA kita. Sifat ini diteruskan dari generasi ke generasi berikutnya dan kita mewarisinya. Lagipula, kita orang Indonesia, dan itu sifat orang Indonesia.

2. Determinisme Psikis, pada dasarnya orangtua kitalah yang berbuat begitu kepada kita. Pegasuhan kita, pengalaman masa anak-anak kita pada dasarnya membentuk kecenderungan pribadi dan susunan karakter kita. Itulah sebabnya kita takut berdiri di depan banyak orang. Begitulah cara orang tua kita membesarkan kita. Kita merasa sangat bersalah jika kita membuat kesalahan karena kita "ingat jauh di dalam hati tentang penulisan naskah emosional kita ketika kita sangat rentan, lembek dan bergantung. Kita "ingat" hukuman emosional, penolakan, pembandingan dengan orang lain ketika kita tidak berprestasi seperti yang diharapkan.

3. Determinisme Lingkungan, pada dasarnya mengatakan bos kita berbuat begitu kepada kita atau pasangan kita, atau anak remaja yang berkital itu, atau situasi ekonomi kita, atau kebijakan nasional. Sesorang atau sesuatu di lingkungan kita betanggungjawab atas situasi kita.

\section{Metode, proses dan langkah}

\section{pembentukan karakter}

1. Metode Pembentukan Karakter

Metode pembentukan karakter berkaitan langsung dengan tahapan 
perkembangannya. Tahapan tersebut terbagi dalam tiga tahapan yaitu tahapankarakter lahiriyah (karakter anak-anak), tahapan karakter berkesadaran (karakter remaja) dan tahapan kontrol internal atas karakter (karakter dewasa). Pada tahapan lahiriyah metoda yang digunakan adalah pengarahan, pembiasaan, keteladanan, penguatan (imbalan) dan pelemahan (hukuman) serta indoktrinasi. Sedangkan pada tahapan perilaku berkesadaran, metoda yang digunakan adalah penanaman nilai melalui dialog yang bertujuan meyakinkan, pembimbingan bukan instruksi dan pelibatan bukan pemaksaan. Dan pada tahapan kontrol internal atas karakter maka metoda yang diterapkan adalah perumusan visi dan misi hidup pribadi, serta penguatan akan tanggungjawab langsung kepada Allah. Tahapan diatas lebih didasarkan pada sifat daripada umur.

2. Proses Pembentukan Karakter

a. Karakter terbentuk setelah mengikuti proses sebagai berikut :

b. Adanya nilai yang diserap seseorang dari berbagai sumber, mungkin agama, ideologi, pendidikan, temuan sendiri atau lainnya.

c. Nilai membentuk pola fikir seseorang yang secara keseluruhan keluar dalam bentuk rumusan visinya.

d. Visi turun ke wilayah hati membentuk suasana jiwa yang secara keseluruhan membentuk mentalitas.

e. Mentalitas mengalir memasuki wilayah fisik dan melahirkan tindakan yang secara keseluruhan disebut sikap. Sikap-sikap yang dominan dalam diri seseorang yang secara keseluruhan mencitrai dirinya adalah apa yang disebut sebagai kepribadian atau karakter. Proses pembentukan mental tersebut menunjukan keterkaitan antara fikiran, perasaan dan tindakan. Dari akal terbentuk pola fikir, dari fisik terbentuk menjadi perilaku. Cara berfikir menjadi visi, cara merasa menjadi mental dan cara berprilaku menjadi karakter. Apabila hal ini 
terjadi terus menerus akan menjadi sebuah kebiasaan.

Terkait dengan hal tersebut, selaras apa yang dikatakan Imam alGhozali bahwa akhlak atau karakter adalah suatu perbuatan yang dilakukan oleh seseorang tanpa melalui proses pemikiran. Jadi, proses pembentukan karakter itu menunjukkan keterkaitan yang erat antara fikiran, perasaan dan tindakan. Dari wilayah akal terbentuk cara berfikir dan dari wilayah fisik terbentuk cara berperilaku. Cara berfikir menjadi visi, cara merasa menjadi mental dan cara berperilaku menjadi karakter.

\section{Langkah Mengubah Karakter}

Dengan mengetahui tahapan, metoda dan proses pembentukan karakter, maka bisa diketahui bahwa akar dari perilaku atau karakter itu adalah cara berfikir dan cara merasa seseorang. Sehingga untuk mengubah karakter seseorang, kita bisa melakukan tiga langkah berikut :

a. Melakukan perbaikan dan pengembangan cara berfikir yang kemudian disebut terapi kognitif, dimana fikiran menjadi akar dari karakter seseorang.

b. Melakukan perbaikan dan pengembangan cara merasa yang disebut dengan terapi mental, karena mental adalah batang karakter yang menjadi sumber tenaga jiwa seseorang

c. Melakukan perbaikan dan pengembangan pada cara bertindak yang disebut dengan terapi fisik, yang mendorong fisik menjadi pelaksana dari arahan akal dan jiwa. Hidup di zaman modern ini semua serba ada, baik dan buruk, halal haram, benar salah nyaris campur menjadi satu, sulit untuk dibedakan. Maka sebaik-baik orang yang dapat memilah dan memilih suatu perbuatan yang baik, karena perbuatan baik ini akan berdampak pada perilaku manusia, ada beberapa hal yang perlu diperhatikan dalam membentuk karakter

A. Upaya Pembentukann Karakter pada Anak Dini Melalui Pembiasaan 
Pembiasaan merupakan bagian penting dalam tahapan penalaran prakonvensional dimana anak mulamula mengembangkan keterampilan hidupnya lebih banyak bergantung pada faktor eksternal. Oleh karena itu, peran orang tua dan guru dalam mengembangkan pembiasaan prilaku baik melalui contoh dan tindakan. Sejalan dengan pertumbuhan dan perkembangan anak, tahapan ini akan berangsur angsur menuju ke tahap konvensional dimana anak mulai mengembangkan nilai pribadi dan menjadikan nilai-nilai tertentu sebagai pemandu prilakunya.

Dalam usaha memberikan pendidikan dan membantu perkembangan anak usia dini, selain pengembangan kecerdasan dan keterampilan, perlu juga sejak dini ditanamkan kebiasaan-kebiasaan yang positif. Pendidikan dengan mengajarkan dan pembiasaan adalah pilar terkuat untuk pendidikan anak usia dini, dan metode paling efektif dalam membentuk iman anak dan meluruskan akhlaknya, sebab metode ini berlandasakan pada pengikutsertaan. Tidak diragukan lagi, Ulwan (1981: 64) menegaskan bahwa mendidik dengan cara pembiasaan anak sejak dini adalah paling menjamin untuk mendatangkan hasil positif, sedangkan mendidik dan melatih setelah dewasa sangat sukar untuk mencapai kesempurnaan. Selanjutnya menurut Kartono (1996: 101), kebiasaan merupakan bentuk tingkah laku yang tetap dari usaha menyesuaikan diri terhadap lingkungan yang mengandung unsur afektif perasaan. Kebiasaan diperoleh dengan jalan latihan, peniruan dan ulangan secara terus menerus, semula semua latihan, peniruan dan ulangan itu berlangsung secara disadari, lambat laun menjadi kurang disadari untuk selanjutnya menjadi otomatis mekanistis, tidak disadari.

Menurut Abdullah Nashih Ulwan (1995) pembiasaan merupakan metode yang sangat tepat dilakukan dalam pendidikan pada usia anakanak karena kecenderungan dan naluri anak-anak dalam pengajaran dan pembiasaan adalah sangat besar di banding usia lainnya. Dan merupakan pilar terkuat dalam pendidikan dan metode paling efektif dalam membentuk iman anak serta meluruskan akhlaknya. Hal tersebut diperkuat oleh hadist Nabi SAW. 
"Perintahkanlah anak anak kalian untuk mengerjakan shalat ketika mereka berumur tujuh tahun dan pukullah mereka (jika tidak mau melaksanakan shalat) ketika berumur sepuluh tahun"

Nabi sendiri telah mengkhususkan waktu 3 tahun berturut-turut untuk menanamkan perintah penting dalam Islam, yaitu perintah shalat. Sudah dimaklumi bersama, betapa penting kedudukan shalat. Oleh karena itu dalam Al Quran disebutkan "perintahkanlah keluargamu mengerjakan shalat dan hendaklah bersabar dalam melaksanakannya". Memang harus bersabar dalam tahun-tahun ini serta dalam mengulang perintah dan tuntutan terhadap anak agar melaksanakan shalat. Secara matematis selama kurun waktu 3 tahun ini jika orang tua memerintahkan anaknya setiap kali tiba waktu shalat, maka kita dapatkan angka yang cukup besar yaitu (5 x 365) x $3=5.475$ kali perintah. Ini merupakan angka yang manunjukkan betapa pentingnya pengulangan dalam memberikan perintah. Sehingga Abdullah bin Mas'ud dalam memberikan pengarahan kepada para bapak, dalam mendidik anak mengatakan, "biasakanlah anakanakmu untuk melakukan kebaikan karena kebaikan itu (terbentuk dari) kebiasaan.” (Suwaid, 2004: 528).

Karena sangat pentingnya pembiasaan di dalam membentuk tingkah laku anak, mengurangi perilaku yang buruk (karena tidak diperlakukan) maka akan muncul pola perilaku baru yang relative menetap dan otomatis maka, membiasakan anak untuk selalu berdoa ketika sebelum, selama dan sesudah melakukan suatu aktivitas adalah hal yang sangat dianjurkan. Karena pada hakikatnya doa merupakan aktivitas ibadah bahkan termasuk kategori ibadah yang mulia, sebab di dalam diri terjadi proses hubungan transcendental antara manusia dengan sang pencipta. Tidak ada ibadah yang lebih utama bagi lidah setelah membaca Al Quran, selain dzikrullah (mengingat Allah) menyampaikan segala tebusan melalui doa yang tulus kepada-Nya. Nabi SAW. mencontohkan didalam mendidik anak-anak beliau dan anakanak para sahabat untuk selalu berdoa.

Berdasarkan HR Muslim, Bukhori, Malik, Abu Dawud, 
Tirmidzi dari Umar bin Abu Salamah di ceritakan bahwa ketika Umar makan bersama Rosulullah, beliau menyuruhnya membaca bismillah, makan dengan tangan kanan dan mengambil makanan yang dekat. (Thalib, 2000: 42). Dalam hadist lain dikatakan bahwa doa itu otaknya ibadah. Di dalam doa itu manusia memuji Allah yang memiliki segala sifat sempurna di atas segala kesempurnaan yang ada. Dengan demikian, secara implisif manusia mengakui kebesaran dan mutlaknya kekuasaan Allah Swt serta kebergantungan hidup kepada-Nya, lalu memohon pertolongan-Nya (Sauri, 2006: 50). Sehingga sangatlah penting membiasakan anak-anak untuk selalu berdoa. Menurut berbagai penelitian, anak dalam kandungan sudah bisa dirangsang dengan hal-hal yang bersifat keagamaan, tatkala mengelus perutnya biasakanlah para ibu untuk mengajarkan agama dengan ucapan basmalah, atau ketika bayi lahir dengan membiasakan azan, doa dan rajin shalat, anak menjadi terbiasa dengan lafazd-lafazd doa. Bayi berusia 1 sampai dengan 2 bulan, sudah mampu merekam keteladanan yang dilakukan ibunya (Warsidi, 2006: 3).

Ketaatan beragama pada usia dewasa sangat dipengaruhi oleh pengalaman beragamanya ketika kecil. Pengulangan kebiasaan beragama itu salah satunya adalah penanaman kebiasaan berdoa. Menurut Abdullah Gymnastiar dalam bukunya kedahsyatan berdoa terungkap bahwa hakikat doa ada pada bagaimana kita semakin dekat kepadaNya. Akibatnya adalah akhlak kita akan terlihat dan terasa makin tinggi dan cemerlang. Dan terdapat nilai yang lebih hakiki dari doa yakni perubahan diri kita menjadi lebih baik, lebih bermutu, lebih dekat kepada Allah. Karena sifat hakiki manusia adalah "homo religius" makhluk beragama yang mempunyai fitrah untuk memahami dan menerima nilai-nilai kebenaran yang bersumber dari agama. Serta sekaligus menjadi kebenaran agama itu sebagai rujukan (referensi) sikap dan perilakunya (Yusuf, 2005: 1).

Jika seseorang sejak kecil ditanamkan kebiasaan yang baik seperti berdoa maka secara otomatis akan menjadi bagian dari tingkah lakunya sehari-hari hingga dewasa. 
Dan kebiasaan itu akan dipupuk dengan pemahaman keagamaan yang lain sesuai dengan kadar akal yang dimiliknya.

Dari hal tersebut akan terwujud kematangan beragama pada diri seseorang, sebagaimana yang didefinisikan Jalaludin Rahmat dalam bukunya psikologi agama bahwa kematangan beragama bisa dilihat dari kemampuan seseorang untuk memahami, menghayati serta mengaplikasikan nilai-nilai luhur agama yang dianutnya dalam kehidupan sehari-hari.

Selanjutnya, secara sederhana ada beberapa hal yang dapat dianggap positif untuk dibiasakan terhadap anak usia dini, di antaranya adalah:

a. Anak harus dibiasakan menjaga kebersihan, sebab Islam sangat mementingkan kebersihan, sebagaimana dapat dibaca pada firman Allah berikut ini:

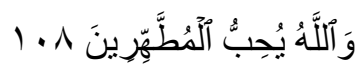

Artinya: "Dan Allah menyukai orang-orang yang bersih".

(Taubah: 108)

Ayat di atas menjelaskan tentang kecintaan Allah terhadap orang yang bersih, yaitu orang menyucikan dirinya dari segala macam najis dan kotoran sekaligus membersihan jiwanya dari segala macam dosa (Ibnu Kasir, 2003: 48). Ayat ini sejalan dengan sabda Rasul:

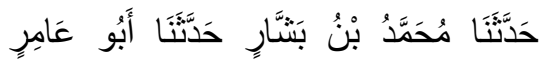

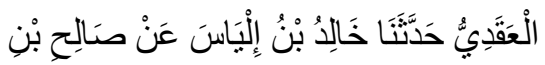

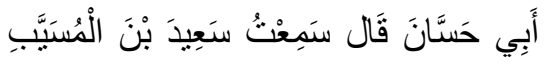

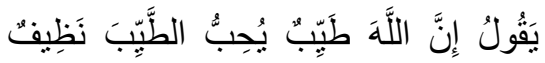

$$
\begin{aligned}
& \text { يُحِبُُ النَّظَافَةَ }
\end{aligned}
$$
kebersihan dengan lingkungan dibentuk melalui proses pendidikan, tetapi kepekaan terhadap kebersihan dibangun melalui proses pembiasaan sejak kecil. Konsistensi orang tua terhadap keharusan anak untuk cuci tangan sebelum makan, cuci kaki sebelum tidur, mandi dan gosok gigi secara tertur, menyapu lantai dan halaman rumah, buang sampah di tempat sampah, menempatkan sepatu ditempatnya, merapikan baju dan buku di kamarnya. Merapikan tempat tidur setiap bangun tidur, adalah merupakan pekerjaan membiasakan 
anak pada hidup bersih hingga kedasaran akan kebersihan itu menjadi bagian dari kepribadiannya.

Pada usia remaja kebersihan harus didukung oleh pengetahuan empirik, misalnya melihat benda dan air kotor, tangan kotor dan sebagainya dengan mikroskup sehingga bisa menyaksikan sendiri kuman-kuman penyakit pada sesuatu yang kotor tersebut. Adapun perilaku bersih pada masyarakat diwujudkan dengan pengaturan yang bersistem, misalnya sistem pemeliharaan kebersihan umum lengkap dengan sarana yang tesedia, sistem sanitasi, sistem pembuangan limbah ditempat umum kemusian didukung dengan peraturan yang menjamin kelangsungan hidup bersih dan tertib. Singapura misalnya mengenakan denda sekitar lima ratus ribu rupiah bagi orang yang hanya membuang puntung rokok secara sembarangan

b. Anak dilatih dan dibiasakan hidup teratur, misalnya dengan membiasakan anak makan secara teratur dan tidak berlebihan, sebagaimana difirmankan Allah:

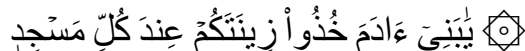

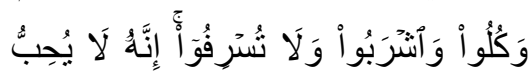

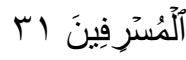

Artinya: "Hai anak Adam, pakailah pakaianmu yang indah di setiap (memasuki) mesjid, makan dan minumlah, dan janganlah berlebihlebihan. Sesungguhnya Allah tidak menyukai orang-orang yang berlebih-lebihan”.(Al A'raaf ayat 31)

Makna yang terdapat pada ayat ini adalah makanlah sesukamu dan berpakaianlah sesukamu selagi engkau hindari dua pekerti, yaitu berlebih-lebihan dan sombong. Allah menghalalkan makan dan minum selagi dilakukan dengan tidak berlebih-lebihan dan tidak untuk kesombongan (Ibnu Kasir, 2003: 289). Dalam hadis Rasul kita temukan tentang aturan makan dan minum, yaitu seperti yang tersebut dalam hadis berikut ini:

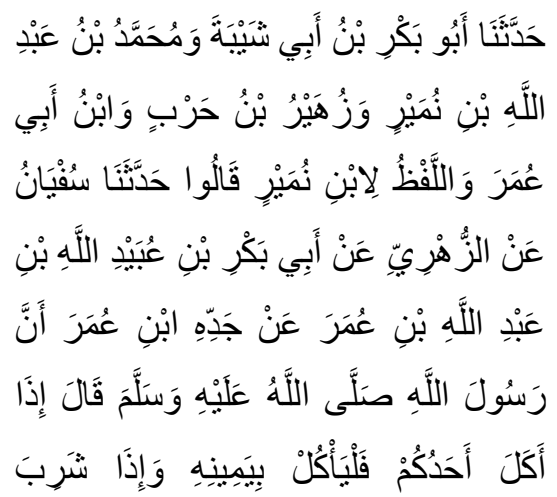




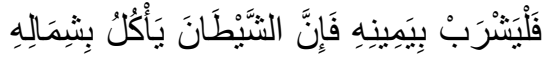

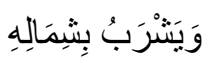

Artinya: Dari Jaddah ibn Umar

Rasulullah berkata: "Jika makan salah seorang diantara kamu, maka makanlah dengan tangan kanan, dan jika minum, maka minumlah dengan tangan kanan, karena sesungguhnya syaitan makan dan minum dengan tangan kiri" (HR. AtTirmizi).

c. Anak sejak dini hendaknya dibiasakan hidup sederhana dan hemat. Untuk itu sebaiknya anak tidak dibiasakan jajan, sebab jajan di samping merupakan kebiasaan yang tidak baik, juga makananan yang ia beli belum terjamin kebersihannya hingga bisa membahayakan kesehatannya (Panitia Muzakarah Ulama, 1988: 58-59). Itulah beberapa metode pendidikan yang menurut hemat penulis layak untuk diterapkan pada pelaksanaan pendidikan anak usia dini. Dengan metodemetode tersebut secara teoritis akan memberikan hasil positif terhadap pembinaan karakter dan pendidikan anak usia dini, baik itu yang dilaksanakan orang tua di rumah, maupun oleh para guru di sekolah/lembaga pendidikan anak usia dini.

\section{Penutup}

Pembiasaan merupakan bagian dari metode mendidik anak yang tujuannya adalah untuk membentuk tingkah laku anak dan mengurangi perilaku yang buruk, dengan demikian maka akan muncul pola perilaku baru yang relative menetap dan otomatis, inilah yang dinamakan karakter. Dalam perspektif Islam karakter berarti akhlak, Jadi, proses pembentukan karakter itu menunjukkan keterkaitan yang erat antara fikiran, perasaan dan tindakan. Dari wilayah akal terbentuk cara berfikir dan dari wilayah fisik terbentuk cara berperilaku. Cara berfikir menjadi visi, cara merasa menjadi mental dan cara berperilaku menjadi karakter. secara sederhana ada beberapa hal yang dapat dianggap positif untuk dibiasakan terhadap anak usia dini, di antaranya adalah :

1). Anak harus dibiasakan menjaga kebersihan, sebab Islam 
sangat mementingkan kebersihan. 2). Anak dilatih dan dibiasakan hidup teratur, misalnya dengan membiasakan anak makan secara teratur dan tidak berlebihan. 3). Anak sejak dini hendaknya dibiasakan hidup sederhana dan hemat.

\section{Referensi}

Al Imam abul Fida Ismail Ibnu Kasir Ad-Dimasyqi, 2003, Tafsir Al Qur'an al-'Ażìm, terjemahan Bahrum Abu Bakar, Tafsir Ibnu Kaśìr juz 8, Bandung: Sinar Baru Algesindo

Imam al-Hafidz Abi 'Abbas Muhammad ibn 'Isa ibn Saurah atTirmiżi, Sunan at-Tirmizi al-Jami'us Şahih, juz 3, Semarang: Toha Putra,tt

Panitia Muzakarah Ulama, 1987/1988.Memelihara

Kelangsungan Hidup Anak Menurut Ajaran Islam, Jakarta: Kerjasama Departemen Agama, MUI dan UNICEF,

Ulwan, Abdullah Nashih ., 1981, Tarbiyatu 'l-Aulad fi-'l-Islam, terjemahan Saifullah Kamalie, Pedoman Pendidikan Anak dalam Islam, Semarang: Asy Syfa'

Ad-Dimasyqi, Al Imam abul Fida Ismail Ibnu Kasir ., 2003, Tafsir Al Qur'an al-'Ażìm, terjemahan Bahrum Abu Bakar, Tafsir Ibnu Kasíir juz 11, Bandung: Sinar Baru Algesindo.

Stephen R. Covey, 2002, Living The 7 Habits (Menerapkan 7 Kebiasaan dalam Kehidupan Sehari-Hari). Alih
Bahasa: Drs. Arvin Sapurna, Jakarta, Binarupa Aksara

Tim Redaksi KBBI,. 2001, Kamus Besar Bahasa Indonesia. Edisi Ketiga. Jakarta: Departemen Pendidikan Nasional \& Balai Pustaka

Lickona, Thomas, 1991, Educating for Character: How our Schools can teach Respect and Responsibility. New York : Bantam Books

Ainain, Abu Ali Khalil .,1985, Falsafah al-Tarbiyah fi al-Quran alKarim., T.tp.: Dar al-Fikr al-'Ara:

Faisal Ismail, 1988, Paradigma Kebudayaan Islam, Yogyakarta: Titihan Ilahi Press.

Sujiono, Yuliani Nurani, 2011., Konsep Dasar Pendidikan Anak Usia Dini, Jakarta: Indeks

Quthb, Muhammad Ali ., 1988, Auladuna fi Dlau-it Tarbiyyatil Islamiyyah, terjemahan Bahrum abu Bakar Ihsan, Bandung: Diponegoro

Abdul Halim, M. Nipan .,2001, Anak Saleh Dambaan Keluarga, Jakarta: Mitra Pustaka

Kartono, Kartini, 1996, Psikologi Umum, Bandung: Mandar Maju

Abdullah Nashih Ulwan, 1995, Pendidikan Anak Dalam Islam, Jakarta: Pustaka Amani

Suwaid, Muhammad, 2004, Mendidik Anak Bersama Nabi, terj. Salafuddin Abu Sayyid, Solo: Pustaka Arafah

Thalib, Muhammad, 2000., Praktek Rasulullah Saw. Mendidik Anak Bidang Aqidah dan Ibadah, Irsyad Baitussalam, Bandung. 
Sofyan Sauri, Membangun ESQ melalui doa, Bandung: Media Hidayah
Warsidi, Edi, 2006., Pentingnya Pendidikan Agama Sejak Dini, Bandung, Pustaka Madani

Syamsu Yusuf, 2005., Psikologi Belajar Agama, Bandung: Pustaka Bani Quraisy, 